\title{
Institutional, inter-organizational, and financial factors in science parks: a study from the perspective of collaborative governance
}

\author{
LINDSAY TEIXEIRA SANT'ANNA ${ }^{1}$ \\ DANY FLÁVIO TONELLI ${ }^{2}$ \\ Teresa Cristina Monteiro Martins ${ }^{3}$ \\ JoÃo PaUlo NASCIMENTO da SILVA ${ }^{3}$ \\ LUIZ MARCELO ANTONIALLI ${ }^{2}$
}

\author{
${ }^{1}$ Faculdades Integradas AdVentistas de Minas Gerais (FADMinAS), LAVRAS - MG, BRAZIL \\ ${ }^{2}$ UniVersidade Federal de LAVRAS (UFLA) / DePARTAMENTO de AdMINISTRAÇÃo E ECONOMIA, LAVRAS - MG, BRAZIL \\ ${ }^{3}$ Universidade Federal de LaVras (UFLA) / Programa de Pós-graduação em AdMinistração, LaVras - MG, BraziL
}

\begin{abstract}
This study investigates the importance of fundamental elements of collaborative arrangements from the perspective of the actors operating in Brazilian science parks, and assesses whether these collaborative arrangements are found in the parks' daily practices. Factor analysis identified ten variables considered most relevant, separated into three factors: (i) individual-commitment and motivation among actors; (ii) inter-organizational- interdependence between parties, the participation of all institutions in decision-making, the involvement of various institutions, and trust; and (iii) financial-funding sources and investments. Frequency analysis identified three elements of collaborative governance, although they are not highly prevalent in Brazilian science parks: commitment among actors, participation of all institutions in decision-making, and investment-related issues.
\end{abstract}

Keywords: Factor analysis. Frequency analysis. Motivation. Commitment. Participation.

Fatores institucionais, interorganizacionais e financeiros em parques tecnológicos: um estudo sob a ótica da governança colaborativa

\section{Resumo}

O objetivo do presente estudo foi o de investigar o nível de importância atribuído pelos atores envolvidos nos parques tecnológicos em operação no Brasil aos elementos fundamentais dos arranjos colaborativos, bem como identificar se os mesmos estão presentes nas práticas cotidianas nos parques. Por meio da análise fatorial foi possível identificar dez variáveis consideradas mais relevantes, reunidas em 03 (três) fatores: (i) individuais- comprometimento e motivação entre os envolvidos; (ii) interorganizacionais- interdependência entre as partes, participação de todas as instituições nos processos decisórios, envolvimento de instituições diversas e confiança e (iii) financeiros- fontes de financiamento e investimentos. Após a utilização da técnica de análise de frequência, três elementos da governança colaborativa foram considerados relevantes, mas que não estão fortemente sedimentados nos parques tecnológicos em operação no país, quais sejam: o comprometimento dos envolvidos, a participação de todas as instituições nos processos decisórios e as questões relacionadas ao investimento.

Palavras-chave: Análise fatorial. Análise de frequência. Motivação. Comprometimento. Participação.

Factores institucionales, interorganizacionales y financieros en parques tecnológicos: un estudio desde la perspectiva de la gobernanza colaborativa

\section{Resumen}

El objetivo del presente estudio fue investigar el nivel de importancia atribuido por los actores involucrados en los parques tecnológicos que operan en Brasil a los elementos fundamentales de los acuerdos de colaboración, así como identificar si estos están presentes en las prácticas diarias en los parques. Mediante el análisis factorial fue posible identificar diez variables consideradas más relevantes, reunidas en 03 (tres) factores: (i) individual: compromiso y motivación entre los involucrados; (ii) interorganizacional, interdependencia entre las partes, participación de todas las instituciones en los procesos decisorios, participación de diferentes instituciones y confianza; y (iii) financiero: fuentes de financiamiento e inversiones. Después de usar la técnica de análisis de frecuencia, tres elementos de la gobernanza colaborativa se consideraron relevantes, pero no están fuertemente consolidados en los parques tecnológicos que operan en el país, a saber: el compromiso de los involucrados, la participación de todas las instituciones en los procesos decisorios y las cuestiones relacionadas con la inversión.

Palabras clave: Análisis factorial. Análisis de frecuencia. Motivación. Compromiso. Participación. 


\section{INTRODUCTION}

The Brazilian experience in creating science parks dates back to the 1980s and 1990s (Zouain \& Plonski, 2006), with the first Brazilian science park created in 1996 in Curitiba (Parque de Software de Curitiba, 2015). Science parks are now a reality in Brazil. Aimed at promoting local development through innovative processes, science parks result from collaborations among various public and private actors, such as local governments, businesses, universities, and research centers (Lacerda \& Fernandes, 2015; Pessoa, Brito, Muniz \& Souza, 2012; Tonelli, Marquesini \& Zambalde, 2015; Vedovello, Judice \& Maculan, 2006). Although research on science parks has advanced in Brazil, especially regarding their potential to promote local development, further studies will improve the understanding of the subject, particularly through the lens of specific theoretical approaches, such as those helping to understand how to articulate the relationships established among heterogeneous actors.

Laimer (2015) and Schmidt and Balestrin (2014) indicate that the elements of inter-organizational relationships involving universities, businesses, and government remain unclear in the context of science parks. Therefore, the authors highlight the need for research in this field. Furthermore, few empirical studies on these enterprises have been conducted to date (Laimer, 2015). Most of those that have, given the epistemological limitations of the literature, note that science parks are similar in terms of the initiatives implemented to foster collaboration and innovation, without further research, and they differ regarding the collaboration strategies adopted (Schmidt \& Balestrin, 2014).

Thus, to further understand collaborations in science parks and to bridge the knowledge gap on this subject, this study investigates the inter-organizational relationships necessary for science parks through the theoretical lens of collaborative governance (CG). CG differs substantially from other types of governance previously explored in Brazilian literature, such as corporate, public, or network governance. CG differs from other governance primarily because CG is developed based on the political science and public administration literature. The CG focus on the search for consensus among actors involved in public policy through a deliberative process extending beyond a mere consultation of actors. Instead, this deliberative process involves decisions permeated and influenced by debates among stakeholders and by the recognition of the importance of the arguments raised in these participation environments (Ansell \& Gash, 2007; Foster-Fishman, Berkowitz \& Lounsbury, 2001; Freeman, 1997; Newman, Barnes, Sullivan \& Knops, 2004; Weber \& Khademian, 2008).

According to Ansell and Gash (2008), CG is characterized by nonlinear stages of interaction between public and private actors in the search for common goals. The analysis of governance regimes appropriate for science parks suggests collaborative precepts should be naturally practiced. Conversely, the actors must feel included in a truly collaborative process for an actual collaboration to occur in science parks, combining efforts in the search for positive results, which is the essence of collaboration for Emerson and Nabatchi (2015). Instead of focusing on the traditional governance approaches of command and control, values created by and exchanges between actors are much more important for CG than accounting activities are (Bryson, Crosby \& Stone, 2015).

Recent studies (Abbud \& Tonelli, 2018; Tonelli, Costa \& Sant'Anna, 2018) conducted a theoretical analysis and an empirical analysis of two science parks through the lens of CG. The present study goes beyond those analyses, as it is an empirical study conducted in 32 science parks in operation throughout Brazil, until December 2015, through the theoretical lens of CG.

Thus, the main objective of the present study is (i) to investigate the level of importance of the actors with a role in science parks in operation in Brazil. In this sense, the specific objectives were raised: (i.i) assign to fundamental elements of collaborative arrangements and (i.ii) to assess whether these collaborative arrangements are found in the daily management practices of science parks. This study is based on the assumption that further understanding the CG elements present in science parks may help to identify problems and to develop strategies suitable for these contexts. 
To achieve the study objectives, collaborative arrangements in science parks are first briefly examined through the theoretical lens of CG. Subsequently, the methodological procedures are described before reporting the results and discussion. Lastly, the final considerations are presented.

\section{SCIENCE PARKS: DYNAMIC COLLABORATION ENVIRONMENTS}

Partnerships between companies and universities are increasingly regarded as an effective means of promoting innovation throughout the economy. Such links benefit companies by increasing their resource base and, therefore, their capacity for innovation and competitiveness (Johnston \& Huggins, 2018).

One of the outcomes of partnerships between universities and the public and private sectors is the science park, which promotes interactions between actors involved in conducting activities generating new knowledge-based products and services. In these cases, the government benefits from the collaboration process as complex public problems, that require knowledge, technology and innovation management, that need to be applied beyond the governmental limits. Collaboration with other spheres, such as the private sector, is essential without facing these problems (Choi \& Robertson, 2014; Steiner, Cassin \& Robazzi, 2008; Zen, 2005). On the other hand, in the absence of shared technical knowledge, a pseudo-transfer of technology may occur (Moeliodihardjo, Soemardi, Brodjonegoro \& Hatakenaka 2012). In practice, the lack of planning and observation of local peculiarities means that companies do not give up the continuity of the innovation process (Rodrigues \& Melo, 2013).

Moeliodihardjo et al. (2012) highlight additional barriers that must be overcome for collaborations between universities and the private sector to give rise to innovative processes and products, including: universities developing their research strategies in isolation from the industry; the prejudice of some academics towards the eminently economic view of businesses; the extreme bureaucracy existing in some institutions, which slow down partnerships; and academia's lack of understanding of the difficulties faced by the industry.

In Brazil, the proposal to create science park stemmed from the joint effort of several public, private, and scientific actors in promoting a public policy of technological development also capable of providing local and regional development (Lacerda \& Fernandes, 2015; Pessoa et al., 2012; Vedovello et al., 2006). However, science parks face several challenges. The movement for science parks started late in Brazil, beginning only in the 1980s and 1990s, and showed negative outcomes, including the discontinuation of initiatives and the lack of specific academic and scientific policies of support and resilience (Zouain \& Plonski, 2006).

Despite the difficulties, the number of science parks has increased in Brazil. In 2014, a study by the National Association of Entities Promoting Innovative Enterprises (Associação Nacional de Entidades Promotora de Empreendimentos Inovadores - Anprotec) indicated that, in 1993, Brazil had 94 science parks throughout the country, 28 of which were in operation (Anprotec, 2014). These initiatives refer to the total of projects that are in the 3 phases of the installation of the parks: design, implementation and operation. Another Anprotec (2015) study points that only 32 parks were considered in operation until December 2015 and project that Brazil will have 95 science parks in operation by 2030.

This increase suggests that, despite all difficulties, both the private and the public sectors benefit from science parks in Brazil. Some benefits are highlighted in the literature: the good infrastructure (security, services, and parking) provided by science parks; the business innovation boost resulting from partnerships between companies and academia (Hansen, Becker, Neff \& Mello, 2012; Lacerda \& Fernandes, 2015; Laimer, 2015), which is a catalyst of symbiosis and knowledge exchange (Hobbs, Link, \& Scott, 2016); the clustering of organizations as a source of innovation, which favors the onset and development of links between different organizations and knowledge flows (Hervás-Oliver \& Albors-Garrigos, 2009; Vásquez-Urriago, Barge-Gil \& Rico, 2016) allowing the identification of common interests that may lead to joint projects (Guillain \& Huriot, 2001); and reduced research uncertainty and costs due to geographic proximity (Feldiman, 1999), which increases the likelihood of an explicit search for innovation partners (Macpherson, 1997). 
Considering such complex collaborative arrangements, more permeable structures of governance, in which the state is not necessarily the protagonist, should be constructed. Brazilian science parks, therefore, deserve further research because they build a collaborative and innovative environment resulting from the interaction among several actors towards reaching a common interest, which is not necessarily a government interest but rather a collective interest. Accordingly, CG is an effective theoretical lens because it proposes combining public and private efforts to solve public problems by creating new public policies, relying on relational components such as commitment to principles, shared motivation, joint-action capacity, mutual social learning, and interaction between interest groups (Ansell \& Gash, 2008; Emerson \& Nabatchi, 2015; Emerson, Nabatchi \& Balogh, 2011; Kallis, Kiparsky \& Norgaard, 2009; Mah \& Hills, 2014; Purdy, 2012).

Importantly, CG can not be understood as merely a consultation process but as two-way communication and influence in decision-making, so the responsibility for achieving common goals is shared between public and private actors (Ansell \& Gash, 2007). Choi and Robertson (2014) suggest conceptualizing CG as decision-making based on deliberative consensus, involving stakeholders from various sectors with their different interests and powers, organized in a way that allows solving complex public problems that could not be addressed by the government alone. Therefore, the merit of GC lies in this opportunity all parties have to influence the decision-making process, in contrast to a traditional bureaucratic model (Robertson \& Choi, 2012). Thus, to create, implement, and operate science parks, multiple actors must work together, each with their role. At this point, Tonelli et al. (2018) emphasize that the universities and research institutes assume the supply of technology, space and human resources, while the government establishes partnerships and enables investments to foster partnerships and innovation with service providers range of varied services.

In this context, CG perfectly fits the model of science parks as an adaptable governance regime because it is proposal values the learning process among actors, emphasizing the creation of collective decision-making structures and processes (Bryson, Crosby, \& Stone, 2015). However, it is important to note that collaborative governance has a robust theoretical basis related to normative aspects that, in practice, can produce effects that are difficult to measure. This is because, the relational aspects involve political capital, agreements and mutual learning (Connick \& Innes, 2010) that generate dissension and conflicts during the process. On the other hand, even in the face of this conflict scenario, collaboration can happen as people recognize that such differences and similarities in the group can create a much richer understanding of problems and solutions, which would not happen in isolated or individual actions (Elias \& Alkadry, 2011). What matters for CG is not the number of partnerships, but the learning they provide to those involved. This learning has happened in mining technology parks, where agreements are celebrated, business roundtables, news dissemination, meetings with companies, all in order to generate a shared understanding between involved, based on the collaborative regime (Tonelli et al., 2018).

Despite the limited research on CG in science parks, studies such as those by Mah and Hills (2014); Saavedra and Budd (2009); and Scott (2015) aimed to understand collaboration in a learning process that included partnerships between universities and research institutes. This collaborative process could provide long-term solutions for environmental issues, such as climate change and technological innovation in the energy market. Thus, plenty of room remains for discussing collaborative arrangements among public and private actors in the search for innovation in CG. 


\section{METHOD}

The procedures of data collection and analysis by factor analysis and data crossing used in this theoretical-empirical study are described below.

\section{Data collection and participants}

The data collection method chosen for this study consisted of administering a structured questionnaire using an online tool. In the first part of the questionnaire, the participants, considering their science park, informed researchers about their perception of the degree of importance of 17 CG categories identified in the most cited articles in the Web of Science database (Ansell \& Gash, 2008; Emerson et al., 2011; Foster-Fishman et al. 2001; Freedman, 1997; Johnston, Hicks, Nan \& Auer, 2010; McDougall, Leeuwis, Bhattarai, Maharjan \& Jiggins, 2013; Weber \& Khademian, 2008; Weber, Lovrich \& Gaffney, 2007) and in Brazilian studies on the subject (Sant'Anna, Tonelli \& Abbud, 2016; Tonelli, Sant'Anna \& Abbud, 2018). The degree of importance was scored on a four-point scale as "not important", "slightly important", "important", and "very important". In the second part of the questionnaire, the participants indicated whether these categories and their phenomena were perceived in their science park, using a three-point scale, by choosing one of the following options: "yes", "yes, but partially", or "no". The pretest was performed with managers of a mining science park.

After constructing the questionnaire, four rounds of e-mails were sent to the chosen sample: members of science parks in operation in Brazil. Thirty-two science parks in operation in Brazil by December 2015 were identified (Box 1) (Anprotec, 2015).

E-mail addresses were retrieved from the websites of the science parks, social networks and other search tools were used to identify the individual contact information of science parks, the government, and private managers. Starting on 11/26/2015, e-mails with a link to the online questionnaire were sent to all contacts of the science parks identified in online searches. The last reply was received on 01/21/2016.

Among the 32 parks in operation, no public or private actor replied to the questionnaire except one, which was the Parque de Software de Curitiba.

Finally, 194 science park managers replied to the email, including representatives of local and state governments, companies headquartered in the science parks, partner companies, federal, state and private universities, partner associations, federal institutes of education, private educational institutions, research institutes and companies, technology institutes, public and private foundations, and a holding company. Subsequently, 12 replies were discarded because the questionnaires were incorrectly completed, which precluded the identification of the institution with which the respondent was associated. 182 replies were considered valid.

Box 1 identifies the participating science parks, their geographical locations and the number of respondents per park. 
Institutional, inter-organizational, and financial factors in science parks: a study from the perspective of collaborative governance
Lindsay Teixeira Sant’Anna | Dany Flávio Tonelli Teresa Cristina Monteiro Martins | João Paulo Nascimento da Silva Luiz Marcelo Antonialli

Box 1

Locations of the participating parks

\begin{tabular}{|c|c|c|}
\hline Science Park & Location & $\begin{array}{l}\text { Number of } \\
\text { respondents }\end{array}$ \\
\hline$B H-T E C$ & Belo Horizonte - MG & 8 \\
\hline TecnoPARQ & Viçosa - MG & 10 \\
\hline PCTI - Parque Científico Tecnológico de Itajubá & Itajubá - MG & 6 \\
\hline Parque Tecnológico - RIO/UFRJ & Rio de Janeiro - RJ & 7 \\
\hline PÓLO BIO-RIO & Rio de Janeiro - RJ & 5 \\
\hline TECNÓPOLIS - Parque Tecnológico Região Serrana PET-TEC & Petrópolis - RJ & 3 \\
\hline CIATEC & Campinas - SP & 5 \\
\hline PARQTEC - São Carlos Science Park & São Carlos - SP & 5 \\
\hline Parque Tecnológico de São José dos Campos & São José dos Campos - SP & 10 \\
\hline Parque Tecnológico UNIVAP & São José dos Campos - SP & 4 \\
\hline Techno Park Campinas & Campinas - SP & 4 \\
\hline Parque Tecnológico de Sorocaba & Sorocaba - SP & 10 \\
\hline Parque Tecnológico Piracicaba "Engenheiro Agrônomo Emílio Bruno Germek" & Piracicaba - SP & 4 \\
\hline Parque Tecnológico de Botucatu & Botucatu - SP & 2 \\
\hline Fundação Parque Tecnológico da Paraíba - PaqTcPB & Campina Grande - PB & 6 \\
\hline Parque Tecnológico da Bahia & Salvador - BA & 5 \\
\hline Porto Digital & Recife - PE & 14 \\
\hline SergipeTec & Aracaju - SE & 1 \\
\hline Parque Tecnológico de Londrina Francisco Sciarra & Londrina - PR & 2 \\
\hline FUNDETEC & Cascavel - PR & 5 \\
\hline PTI Parque Tecnológicoltaipu & Foz do Iguaçu - PR & 11 \\
\hline Parque Tecno-Científico da Unicentro - TECNICENTRO & Guarapuava - PR & 4 \\
\hline Parque de Software de Curitiba & Curitiba - PR & 0 \\
\hline $\begin{array}{c}\text { Associação de Desenvolvimento Tecnológico do Vale- } \\
\text { VALETEC - Parque Tecnológico Vale dos Sinos }\end{array}$ & Campo Bom - RS & 13 \\
\hline Parque Científico e Tecnológico da PUCRS (Tecnopuc) & Porto Alegre - RS & 7 \\
\hline Tecnosinos & São Leopoldo - RS & 10 \\
\hline UlbraTECH & Canoas - RS & 1 \\
\hline Parque Científico e Tecnológico - UNIVATES - TECNOVATES & Lajeado - RS & 2 \\
\hline Bianchini Business Park & Blumenau - SC & 3 \\
\hline Sapiens Parque & Florianópolis - SC & 6 \\
\hline ParqTec Alfa & Florianópolis - SC & 4 \\
\hline \multirow[t]{2}{*}{ InovaParque } & Joinville - SC & 5 \\
\hline & & 182 \\
\hline
\end{tabular}

Source: Elaborated by the authors.

Box 2 specifies the respondents, including park managers, managers of partner and/or incubated companies, municipal and state government representatives, and representatives of universities and other institutions. The term "other institutions" encompasses public and private foundations, research companies, technology institutes, federal education and research institutes, private institutions and partner associations. 
Institutional, inter-organizational, and financial factors in science parks: a study from the perspective of collaborative governance
Lindsay Teixeira Sant'Anna | Dany Flávio Tonelli Teresa Cristina Monteiro Martins | João Paulo Nascimento da Silva Luiz Marcelo Antonialli

Box 2

Respondent specifications

\begin{tabular}{|c|c|c|c|c|c|}
\hline Science Park & Managers & Companies & Governments & Universities & Others \\
\hline$B H-T E C / U F M G$ & 1 & 7 & 0 & 0 & 0 \\
\hline TecnoPARQ/UFV & 6 & 3 & 1 & 0 & 0 \\
\hline PCTI - Parque Científico Tecnológico de Itajubá/ UNIFEI & 0 & 5 & 0 & 1 & 0 \\
\hline ParqSource: ue Tecnológico - RIO/UFRJ & 4 & 1 & 1 & 1 & 0 \\
\hline PÓLO BIO-RIO/ UFRJ & 1 & 4 & 0 & 0 & 0 \\
\hline TECNÓPOLIS - Parque Tecnológico RegiãoSerrana PET-TEC/UFF & 1 & 1 & 0 & 0 & 1 \\
\hline CIATEC/ UNICAMP & 0 & 5 & 0 & 0 & 0 \\
\hline PARQTEC - São Carlos Science Park/USP/ UFSCar & 1 & 2 & 0 & 0 & 2 \\
\hline Parque Tecnológico de São José dos Campos/Unifesp/ Unesp & 1 & 3 & 1 & 2 & 3 \\
\hline Parque Tecnológico UNIVAP & 0 & 4 & 0 & 0 & 0 \\
\hline Techno Park Campinas/ UNICAMP & 1 & 1 & 0 & 1 & 1 \\
\hline Parque Tecnológico de Sorocaba/ UNIVESP/UNISINO & 2 & 3 & 0 & 3 & 2 \\
\hline $\begin{array}{c}\text { Parque Tecnológico Piracicaba } \\
\text { "Engenheiro Agrônomo Emílio Bruno Germek"/ ESALQ }\end{array}$ & 0 & 3 & 0 & 1 & 0 \\
\hline Parque Tecnológico de Botucatu/ UNESP & 0 & 1 & 1 & 0 & 0 \\
\hline Fundação Parque Tecnológico da Paraíba - PaqTcPB/ UEPB/ UFCG & 0 & 6 & 0 & 0 & 0 \\
\hline Parque Tecnológico da Bahia/ UFBA & 0 & 1 & 1 & 2 & 1 \\
\hline Porto Digital/ UPE & 6 & 7 & 0 & 1 & 0 \\
\hline SergipeTec/UTFPR & 1 & 0 & 0 & 0 & 0 \\
\hline Parque Tecnológico de Londrina Francisco Sciarra/ UTFPR & 1 & 0 & 0 & 1 & 0 \\
\hline FUNDETEC/UNIOESTE/UTFPR & 3 & 2 & 0 & 0 & 0 \\
\hline PTI-Parque Tecnológico Itaipu/IFPR & 2 & 6 & 0 & 1 & 2 \\
\hline Parque Tecno-Científico da Unicentro - TECNICENTRO/UNICENTRO & 1 & 1 & 0 & 0 & 2 \\
\hline Parque de Software de Curitiba/ UTFPR & 0 & 0 & 0 & 0 & 0 \\
\hline VALETEC - Parque Tecnológico Vale dos Sinos/ASPEUR & 1 & 8 & 1 & 1 & 2 \\
\hline Parque Científico e Tecnológico da PUCRS (Tecnopuc)/ PUC & 1 & 6 & 0 & 0 & 0 \\
\hline Tecnosinos/UNISINOS & 2 & 6 & 1 & 1 & 0 \\
\hline UlbraTECH/ ULBRA & 0 & 1 & 0 & 0 & 0 \\
\hline Parque Científico e Tecnológico - TECNOVATES/UNIVATES & 1 & 1 & 0 & 0 & 0 \\
\hline Bianchini Business Park/ FURB & 2 & 0 & 1 & 0 & 0 \\
\hline Sapiens Parque/ UDESC & 2 & 1 & 0 & 2 & 1 \\
\hline ParqTec Alfa/ UFSC & 1 & 2 & 0 & 1 & 0 \\
\hline InovaParque/UFSC & 1 & 4 & 0 & 0 & 0 \\
\hline TOTAL NUMBER OF RESPONDENTS & 43 & 95 & 8 & 19 & 17 \\
\hline
\end{tabular}

Source: Elaborated by the authors.

Clearly, Box 2 shows most respondents were from partner companies and companies headquartered in the science parks, which demonstrated stronger participation of private actors in the study in numerical terms. 


\section{Factor analysis and crossing of variables}

Data analysis was started after finding no missing data or outliers, because the questionnaire was requested a mandatory answer for all items in the questionnaire. Incomplete questionnaires were excluded from the survey. This analysis was performed to ensure data reliability, where missing data may represent failures in data collection, which may compromise reliability (Corrar, Paulo \& Dias, 2009). The validity of the sample size also was checked. According to Hair, Anderson, Tathan and Black (2005), for robust results in exploratory factor analysis, the sample must be higher than 100 and the ratio between the number of cases and the number of variables must be higher than or equal to 5 . Based on these parameters, the sample is adequate, as it represents all its continuous variables and the ratio between the number of valid responses (182) and the number of Radar variables (17), is higher than 10.

The first technique used was factor analysis, to reduce the 17 variables to factors combining CG elements present in science parks (Hair et al., 2005). To assess the importance respondents assign to CG factors found by factor analysis and how they were being used in science parks, analyses were performed using descriptive statistical techniques. Descriptive statistics summarize and organize data for the identification of patterns and the better visualization of data to facilitate conclusions about the groups of variables found (Oliveira, 2007).

The descriptive statistics technique used to assess the importance respondents attributed to each of the 17 variables comprising the constructs found was frequency analysis. Frequency analysis adequately describes interval variables, such as those measuring the perception of importance (Pereira, 2004). After this analysis, the variables expressing the implementation or not of CG initiatives classified as important or not by the respondents in block 1 were identified among the variables of the second block of the questionnaire: those referring to the effective implementation of CG initiatives in the science parks.

To relate the importance attributed by respondents to the effective application of CG guidelines, the variables were crossed, as frequency tables are insufficient to analyze the relationship between the frequencies of different variables (Pereira, 2004).

The function used to cross the variables in SPSS was crosstabs, through which the cross-classification tables are displayed, making it easier to count the percentage of cells, rows, and columns (Malhotra, 2011).

\section{RESULTS AND DISCUSSION}

The data were subjected to factor analysis to classify collaborative elements the participants considered important, forming constructs maximizing the explanatory power of the whole set of variables towards a synthetic understanding of which collaborative and relational elements the participants consider important in their work in science parks.

First, the Kaiser-Meyer-Olkin (KMO) and Bartlett's tests were applied. These tests are considered prerequisites for assessing the adequacy of the factor analysis technique for the categorization of variables (Hair et al., 2005). Although both tests were significant, the commonality value was used for the final test of inclusion or exclusion of variables, considering values higher than 0.5 representative of a significant association between the variable and the extracted factor. The communality value expresses the proportion of variance for each variable included in the analysis, which is explained by the extracted components; thus, variables with commonality lower than 0.5 should be excluded to ensure the variables remaining in the analysis are linearly correlated (Figueiredo \& Silva, 2010). Based on the commonality values, 7 of the initial 17 study variables were excluded: $15,16,17,19,112,115$, and 117 . 
After the exclusion, Bartlett's sphericity test returned a significance level of the analysis with an error smaller than $1 \%$, and the KMO returned a value of 0.82 . These values indicate the factor analysis is significant (Hair et al., 2005).

The factors were extracted using the Principal Components Analysis method. This technique is commonly used in exploratory research in order to synthesize variables according to the similarity between their variances. This method represents less occurrence of problems that could invalidate the analysis and provides similar results if the commonality of most factors is higher than or equal to 0.6 , which occurred for all variables maintained in the analysis (Hair et al., 2005). As it is an exploratory research, the number of factors has not been previously defined, and it is up to the researchers to consider the factors whose eigenvalues were higher than 1.

The variables were then grouped into three categories: two groups consisted of two variables, and one group consisted of four variables. The variables were grouped by displaying the rotated factor loading matrix using the varimax method, sorted by factor loadings, eliminating factor loadings smaller than 0.6. Thus, the application of the method grouped the variables into three factors, which were renamed into three groups based on the literature: Group 1, which represents institutional factors; Group 2, which represents relational factors; and Group 3 with financial factors.

Box 3 outlines the variables representing CG elements in science parks, the questionnaire items corresponding to each variable, the factor loadings allowing the variables to be grouped and the constructs identified after the analysis.

Box 3

Collaborative governance variables considered relevant by the participants

\begin{tabular}{|c|c|c|c|c|}
\hline & Questionnaire item & 1 & 2 & 3 \\
\hline \multirow{2}{*}{ 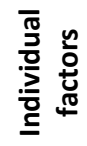 } & I10. COMMITMENT of the actors to creating, developing, and maintaining the science park. & 0.878 & & \\
\hline & I11.MOTIVATION of the actors to develop the science park. & 0.804 & & \\
\hline \multirow{4}{*}{ 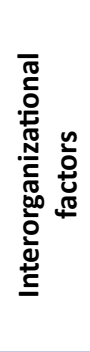 } & $\begin{array}{l}\text { I2. INTERDEPENDENCE BETWEEN PARTIES: clear perception that the best results are achieved } \\
\text { through partnerships. }\end{array}$ & & 0.765 & \\
\hline & $\begin{array}{l}\text { 14. PARTICIPATION OF ALL INSTITUTIONS IN DECISION-MAKING, so all actors have a voice in } \\
\text { the decisions of the upper management of the science park. }\end{array}$ & & 0.693 & \\
\hline & $\begin{array}{l}\text { I1. INVOLVEMENT OFVARIOUS INSTITUTIONS, such as government(s), companies, universities, } \\
\text { organized civil society, community, and other governmental and/or private bodies. }\end{array}$ & & 0.687 & \\
\hline & $\begin{array}{l}\text { 13. TRUST BETWEEN PARTNER INSTITUTIONS in sharing information on subjects of interest of } \\
\text { the science park. }\end{array}$ & & 0.668 & \\
\hline \multirow{2}{*}{ 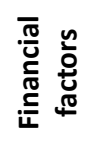 } & 18. INVESTMENT in the science park staff and infrastructure. & & & 0.798 \\
\hline & P14. VARIOUS FUNDING SOURCES, public and private. & & & 0.773 \\
\hline
\end{tabular}

Source: Elaborated by the authors.

Thus, the 10 collaborative variables most relevant to the participants were categorized into three groups, which are described as follows:

Group 1 - Institutional factors (4 variables): all variables categorized into this group share one characteristic: they refer to individual aspects of engagement, such as predisposition to collaboration. Regarding these aforementioned aspects, Tolbert and Zucker (1996) explain the main components of institutionalization are the development of standardized problem-solving behaviors, the combination of such behaviors with specific stimuli, and the development of general and shared social meanings linked to these behaviors. In this context, for innovation, motivation is the sine qua non condition because partners from different fields start collaborations to find innovative solutions, acquire new knowledge, and use new approaches and methods (Rajalo \&Vadi, 2017). 
The results show that the commitment of actors to the creation, development, and maintenance of the science park and their motivations to develop the science park were significant factors indicated by the study participants.

Statistically, the motivation and commitment of actors are strongly correlated. For Johnston and Huggins (2018), the selection of partners for collaborative work with universities requires the ability to assess the extent to which actors actually deliver their promised contributions of knowledge and experience.

Thus, permanent motivation is often associated with the commitment of the actors to the process because when the individuals are more motivated, they will be more committed (Ansell \& Gash, 2008; Emerson et al., 2011; Weber et al., 2007). As a result, these two individual factors promote learning among actors in companies and universities, leveraging specific skills for expert knowledge acquisition (Johnston \& Huggins, 2018).

Group 2 - Interorganizational factors (4 variables): variables of interdependence between parties (participation of all institutions in decision-making, the involvement of various institutions and trust between them) were grouped because of their strong correlation, based on the literature and on the fact that all variables referred to relationships established between science parks and other organizations. Thus, this group for the statistical method, was termed inter-organizational factors.

The variables in this group are important for CG because they involve relationships between multiple actors. CG requires actors be motivated to stimulate an inclusive decision-making process (Foster-Fishman et al., 2001), which entails developing trust relationships between the organizations involved in the process (Emerson et al., 2011; McDougall et al., 2013; Rajalo \& Vadi, 2017) and increasing the interdependence between parties (Ansell \& Gash, 2007; Freedman,1997).

An inclusive deliberative process is so important the literature indicates its influential role in building trust because when the participation is stronger and more inclusive, the trust between actors will be greater (Freeman, 1997; McDougall et al., 2013; Johnston et al., 2010). Accordingly, Johnston et al. (2010) highlight that both the inclusion of all interested parties at once and an excessively slow inclusion can make it difficult to build trust and to strengthen collaborations. Thus, the time necessary for inclusions must be respected to build trust among stakeholders over time because "Certainly, the cost of slowing down the collaborative process is high, but it may be lower than the cost associated with the breakdown of trust" (Johnston et al., 2010, p. 715). Thus, regardless of the number of participants and of the speed with decisions are made, Elias and Alkadry $(2011$, p. 875) briefly explain that, although decision-making processes may start with some scattered and seemingly disconnected ideas, they result in a continuous flow of other ideas ina "process whereby internal logic can only be understood from within the process, in the eyes and words of those participating in it".

Group 3 - Financial factors ( 2 variables): investment in science park staff and infrastructure development and the creation of various public and private funding sources were the variables included in group 3: financial factors. Factor analysis grouped two variables referring to financial means necessary for science parks to conduct their activities. According to the literature, the longevity of a CG regime is affected by financial factors. According to Weber et al. (2007), investment and various funding sources directly influence the longevity of collaborations. The time factor is considered important because when the CG regime is longer, it will externalize adaptation skills to the impacts of joint actions more and it will likely increase their performance more (Emerson et al., 2011; Gazley, 2010). Thus, if the various funding sources are highly important for the actors, the CG regime is even more important for the durability of the collaboration. For Ansell and Gash (2007) and Gazley (2010), the time factor, i.e., the durability of the partnership, is deemed an element of the success of a CG.

In conclusion, CG characteristics applied to science parks can be grouped into three factors - institutional, inter-organizational, and financial - and the elements considered more relevant to the actors are strongly correlated with the international literature on CG (Sant'Anna et al., 2016; Tonelli et al., 2018).

Frequency analysis showed that, except for one variable (participation of all institutions in decision-making), more than $90 \%$ of the respondents considered "important" or "very important" all 10 of the most relevant variables indicated in the factor analysis. Thus, these relevant variables were also related to their applicability in the science parks in operation. These 
variables were crossed with variables from the second block of questions on whether that characteristic can be identified in the science park of the respondent. Then, the participant indicated whether the variable was present with "yes", or whether it was partially present with "yes, but partially", or whether the variable was absent, with a "no".

Table 1 outlines the variables of the factor analysis of Box 1 and their indices of importance for the participants and the percentage of respondents who stated such a variable is fully or partially present in or absent from the science park. Column "I" refers to respondents who considered each variable important or very important, and column " $\mathrm{A}$ " refers to respondents who fully or partially identified the variable in the science park.

Table 1

Crossing of variables

\begin{tabular}{|c|c|c|c|c|}
\hline \multicolumn{3}{|r|}{ QUESTIONNAIRE ITEM } & 1 & A \\
\hline \multicolumn{5}{|c|}{ INDIVIDUAL FACTORS } \\
\hline 110 & $\mathrm{~A} 27$ & COMMITMENT & $95.3 \%$ & $77.7 \%$ \\
\hline 111 & $\mathrm{~A} 28$ & MOTIVATION & $95.8 \%$ & $94.3 \%$ \\
\hline \multicolumn{5}{|c|}{ INTER-ORGANIZATIONAL FACTORS } \\
\hline 12 & A19 & INTERDEPENDENCE BETWEEN PARTIES & $94.8 \%$ & $91.2 \%$ \\
\hline 14 & A21 & PARTICIPATION OF ALL INSTITUTIONS IN DECISION-MAKING & $84 \%$ & $76.7 \%$ \\
\hline 11 & A18 & INVOLVEMENT OF VARIOUS INSTITUTIONS & $96.9 \%$ & $93.8 \%$ \\
\hline 13 & $\mathrm{~A} 20$ & TRUST BETWEEN PARTNER INSTITUTIONS & $96.9 \%$ & $91.7 \%$ \\
\hline \multicolumn{5}{|c|}{ FINANCIAL FACTORS } \\
\hline 18 & A25 & INVESTMENT & $96.9 \%$ & $76.7 \%$ \\
\hline 114 & A31 & VARIOUS FUNDING SOURCES & $95.4 \%$ & $81.4 \%$ \\
\hline
\end{tabular}

Source: Elaborated by the authors.

The variables with the lowest percentage of applicability in the science parks, according to the perception of the participants, were commitment, participation in decision-making, and investment. These variables ranged from $76.7 \%$ to $77.7 \%$, whereas the others surpassed $81 \%$. Although it is the variables with the least perception of practical application in the routines of the researched parks, all are important variables for the collaborative process and recognized as such by the interviewees.

The low level of commitment to the science parks in operation perceived by the actors is a compromising factor of collaboration. As Ansell and Gash (2008), Emerson et al. (2011), and Weber et al. (2007) clarify, the commitment to the process is directly linked to the durability of the partnership. Therefore, the lack of commitment perceived by the actors may end some partnerships in the science parks.

Interestingly, the literature indicates a direct relationship between the commitment and the participation of actors in collaborations. When participation occurs, responsibility sharing and mutual accountability should also occur beyond the division between the public and private sectors; regardless of which sector the actors belong to, they must feel responsible for the results (Freedman, 1997). This direct relationship is confirmed in the survey, as $77.7 \%$ of respondents acknowledge that they are committed to the process and slightly less (76.7\%) say that they participate in decision-making processes in the parks. The fact that $23.3 \%$ of respondents do not participate in the decisions in the parks may reflect a possible culture of centralizing decision-making processes in the parks, which discourages the construction of a collaborative environment.

Although investment is considered a very important variable by almost all respondents ( $96.9 \%)$, only $76.7 \%$ of the respondents stated funds are invested in their science parks, albeit partially. Thus, $23.3 \%$ of the respondents stated no funds are invested in the development of their science parks, although only $1.5 \%$ of respondents did not consider investments important. Clearly, some barriers must be overcome to widen the range of investments required for the durability of collaborations in science parks. Investments a very important factor for starting and continuing a collaborative initiative. Thus, in the words of Weber and Khademian (2008, p. 341), the local government should serve "as a catalyst for partnerships", especially in the presence of public objectives in the network. The municipal and state governments involved in science parks should attract 
partnerships through investment or by building trust so other actors also invest in the process (Weber \& Khademian, 2008), as every collaborative project starts with uncertainties about the knowledge and investment of each partner (Johnston \& Huggins, 2018). Thus, the presence of the government not only ensures constant investments but also maintains the research agenda of universities (Perkmann et al., 2013), which is threatened when the sole purpose of the partnership is the profit of the private company.

Among inter-organizational factors, the respondents highlighted the trust, interdependence, and participation of various institutions as important or very important, in addition to informing researchers these values are put into practice in their institutions. This result is important, as the new orientation of public policy design lies precisely in this variety of different actors interacting with each other over time, each with different interests and resources and with knowledge and information limitations (Howlett, 2014).

The respondents also considered important the participation of various institutions in decision-making, yet the percentage of respondents who valued this variable was lower. Although $84 \%$ of the participants recognized the importance of an inclusive decision-making process, this element was not found in initiatives implemented in the science parks, suggesting a possible culture of centralized decision-making in science parks.

The analysis of all factors thus shows the need for improving the commitment of the actors, their participation in decision-making, and investments in science parks.

\section{FINAL CONSIDERATIONS}

The overall objective of the present study was (i) to investigate the level of importance of the actors with a role in science parks in operation in Brazil. Specifically, (i.i) to identify the collaborative elements considered important by actors of science parks in operation in Brazil and to (i.ii) assess whether they are found in the practices implemented in science parks, according to the perception of the actors.

Seventeen CG theoretical constructs were identified in the international literature, which were used to prepare a questionnaire sent to managers of organizations involved in the science parks identified in this study. Based on the questionnaires, a factor analysis was performed, which showed the actors considered 10 variables to be more relevant than the others. These variables were organized into three groups: institutional factors (commitment among actors, motivation, knowledge, expertise and experience sharing and transfer, practices, and results from initiatives consistent with the institutionalized discourse), inter-organizational factors (interdependence between parties, participation of all institutions in decision-making, involvement of various institutions, and trust) and financial factors (various funding sources and investments). Frequency analysis was also performed to investigate relationships between relevant variables and their applicability in science parks in operation. The results of the factor and frequency analyses help to understand more objectively and practically which collaborative elements are considered more or less relevant to the actors of the 32 science parks in operation in Brazil.

The following three CG elements considered relevant in the literature (Ansell \& Gash, 2008; Emerson et al., 2011; Freedman, 1997; Sant'Anna et al., 2016; Weber \& Khademian, 2008; Weber et al., 2007) were not identified in science parks in operation in Brazil: the commitment of actors, participation of all institutions in decision-making, and investments.The partial presence or absence of these elements compromises the start and continuation of collaborations in science parks.

Thus, this study bridges a key gap in the literature on CG elements perceived and implemented in practices developed in science parks in operation in Brazil. However, further studies are still needed to understand the reasons for differences in the recognition of the importance of commitment, participation in decision-making and investments, and their effective practice in science parks.

\section{ACKNOWLEDGMENTS}

The authors are grateful for the support of FAPEMIG for the development of this research. 


\section{REFERENCES}

Abbud, E. B., \& Tonelli, D. F. (2018). Governança colaborativa: implantação de Parques tecnológicos pelo governo de MG. Revista de Administração e Contabilidade da Unisinos, 15(2), 95-110. Retrieved from https://doi.org/10.4013/base.2018.152.02

Abramovsky, L., \& Simpson, H. (2011). Geographic proximity and firmuniversity innovation linkages: evidence from Great Britain. Journal of Economic Geography, 11, 949-977. Retrieved from https://doi. org/10.1920/wp.ifs.2009.0903

Ansell, C., \& Gash, A. (2008). Collaborative governance in theory and practice.Journal of Public Administration Research and Theory, 18(4), 543-571. Retrieved from https://doi.org/10.1093/jopart/mum032

Associação Nacional de Entidades Promotoras de Empreendimentos Inovadores. (2014). Estudo de Projetos de Alta Complexidade: Indicadores de Parques Tecnológicos. Retrieved from http://www. anprotec.org.br/Relata/PNI_FINAL_web.pdf

Associação Nacional de Entidades Promotoras de Empreendimentos Inovadores. (2015). Propostas de Políticas Públicas para Parques Tecnológicos e Incubadora de Empresas. Retrieved from http://ppi. certi.org.br/4-PropostasPoliticasPublicasParquesIncubadoras.pdf

Bryson, J. M., Crosby, B. C., \& Stone, M. M. (2015). Designing and Implementing Cross-Sector Collaborations: Needed and Challenging. Public Administration Review, 75(5), 647-663. Retrieved from https:// doi.org/10.1111/puar.12432

Choi, T., \& Robertson, P. J. (2014). Caucuses in Collaborative Governance: Modeling the Effects of Structure, Power, and Problem Complexity. International Public Management Journal, 17(2), 224 254. Retrieved from https://doi.org/10.1080/10967494.2014.905398

Connick, S., \& Innes, J. (2010). Outcomes of collaborative water policy making: applying complexity thinking to evaluation. Journal of Environmental Planning and Management, 46, 177-197. Retrieved from https://doi.org/10.1080/0964056032000070987

Corrar, L. J., Paulo, E., \& Dias, J. M., Filho. (Coord.). (2007). Análise multivariada para os cursos de Administração, Ciências Contábeis e Economia. São Paulo, SP: Atlas.

Elías, M. V., \& Alkadry, M. G. (2011). Constructive Conflict, Participation, and Shared Governance. Administration \& Society, 43(8), 869-895. Retrieved from https://doi.org/10.1177/0095399711422495

Emerson, K., \& Nabatchi, T. (2015). Evaluating the Productivity of Collaborative Governance Regimes: A Performance Matrix. Public Performance \& Management Review, 38(4), 717-747. Retrieved from https://doi.org/10.1080/15309576.2015.1031016

Emerson, K., Nabatchi, T., \& Balogh, S. (2011). An Integrative Framework for Collaborative Governance. Journal of Public Administration Research and Theory, 22(1), 1-29. Retrieved from https://doi.org/10.1093/ jopart/mur011

Figueiredo, D. B., Filho, \& Silva, J. A. S., Jr. (2010). Visão além do alcance: uma introdução à análise fatorial. Opinião Pública, 16(1), 160-185. Retrieved from https://doi.org/10.1590/s0104-62762010000100007

Foster-Fishman, P. G., Berkowitz, S. L., \& Lounsbury, D. W. (2001). Building Collaborative Capacity in Community. American Journal of
Community Psychology, 29(2), 241-261. Retrieved from https://doi. org/10.1023/A:1010378613583

Freeman, J. (1997). Collaborative governance in the administrative state. Ucla Law Review, 45(1), 1-98. Retrieved from https://ssrn. com/abstract $=11408$

Guillain, R., \& Huriot, J. M. (2001). The local dimension of information spillovers: a critical review of empirical evidence in the case of innovation. Canadian Journal of Regional Science, 24(2), 313-338. Retrieved from http://www.cjrs-rcsr.org/archives/24-2/8-GuillainHuriot.pdf

Hair J. F., Jr., Anderson, R. E., Tathan, R. L., \& Black, W. C. (2005). Análise multivariada de dados. Porto Alegre, RS: Bookman.

Hansen, P. B., Becker, G. V., Neff, H. B., \& Mello, N. C. (2012). Contribuição do parque tecnológico para a competitividade das empresas instaladas: análise do caso do Tecnopuc - RS. Revista Gestão Organizacional, 5(2), 193-213. Retrieved from http://www.spell.org.br/documentos/ ver/10337/contribuicao-do-parque-tecnologico-para-a-competitividadedas empresas-instaladas--analise-do-caso-do-tecnopuc-----rs/i/pt-br

Hervás-Oliver, J. L., \& Albors-Garrigos, J. (2009). The role of firm's internal and relational capabilities in clusters: when distance and embeddedness are not enough to explain innovation. Journal of Economic Geography, 9(2), 263-283. Retrieved from https://doi. org/10.1093/jeg/lbn033

Hobbs, K. G., Link, A. N., \& Scott, J. T. (2017). Science and technology parks: an annotated and analytical literature review. Journal of Technology Transfer, 42, 957-976. Retrieved from https://doi. org/10.1007/s10961-016-9522-3

Howlett, M. (2014). From the 'old' to the 'new' policy design: design thinking beyond markets and collaborative governance. Policy Science, 47, 87-207. Retrieved from https://doi.org/10.1007/s11077-014-9199-0

Johnston, A., \& Huggins, R. (2018). Partner selection and universityindustry linkages: Assessing small firms'initial perceptions of the credibility of their partners. Technovation, 78, 15-26. Retrieved from https://doi.org/10.1016/j.technovation.2018.02.005

Johnston, E. W., Hicks, D., Nan, N., \& Auer, J. C. (2010). Managing the Inclusion Process in Collaborative Governance.Journal of Public Administration Research and Theory, 21(4), 699-721. Retrieved from https://doi.org/10.1093/jopart/muq045

Kallis, G., Kiparsky, M., \& Norgaard, R. (2009). Collaborative governance and adaptive management: Lessons from California's CALFED Water Program. Environmental Science \&Policy, 12(6), 631-643. Retrieved from https://doi.org/10.1016/j.envsci.2009.07.002

Lacerda, N., \& Fernandes, A. C. (2015). Parques tecnológicos: entre inovação e renda imobiliária no contexto da cidade do Recife. Cadernos Metrópole, 17(34), 329-354. Retrieved from https://doi. org/10.1590/2236-9996.2015-3402

Laimer, C. G. (2015). Determinants of interorganizational relationships in science and technology parks: theoretical and empirical evidence. Gestão \& Regionalidade, 31(91), 122-137. Retrieved from https:// doi.org/10.13037/gr.vol31n91.2836 
Institutional, inter-organizational, and financial factors in science parks: a study from the perspective of collaborative governance
Lindsay Teixeira Sant'Anna | Dany Flávio Tonelli Teresa Cristina Monteiro Martins | João Paulo Nascimento da Silva Luiz Marcelo Antonialli
MacPherson, A. (1997). The role of producer service outsourcing in the innovation performance of New York state manufacturing firms. Journal Annals of the Association of American Geographers, 87(1), 52-71. Retrieved from https://doi.org/10.1111/0004-5608.00041

Mah, D. N. Y., \& Hills, P. (2014). Collaborative governance for technological innovation: a comparative case study of wind energy in Xinjiang, Shanghai, and Guangdong. Environment and Planning C: Government and Policy, 32(3), 509-529. Retrieved from https:// doi.org/10.1068/c11101

Malhotra, N. K. (2011). Pesquisa de marketing: foco na decisão. São Paulo, SP: Pearson.

McDougall, C. L., Leeuwis, C., Bhattarai, T., Maharjan, M. R., \& Jiggins, J. (2013). Engaging women and the poor: adaptive collaborative governance of community forests in Nepal. Agriculture and Human Values, 30(4), 569-585. Retrieved from https://doi.org/10.1007/ s10460-013-9434-x

Moeliodihardjo, B. Y., Soemardi, B. W., Brodjonegoro, S. S., \& Hatakenaka, S. (2012). University, Industry, and Government partnership: its present and future challenges in Indonesia. Procedia Social and Behavioral Sciences, 52, 307-316. Retrieved from https:// doi.org/10.1016/j.sbspro.2012.09.468

Newman, J., Barnes, M., Sullivan, H., \& Knops, A. (2004). Public Participation and Collaborative Governance. Journal of Social Policy, 33(2), 203-223. Retrieved from https://doi.org/10.1017/ S0047279403007499

Oliveira, F. E. M. (2007). SPSS básico para análise de dados. Rio de Janeiro, RJ: Ciência Moderna.

Parque de Software de Curitiba. (2017). História. Retrieved from http://www.parquedesoftware.com.br/Historia-27-57.shtml

Pereira, A. (2004). Guia prático de utilização do SPSS: Análise de dados para ciências sociais e psicologia. Lisboa, Portugal: Sílabo.

Perkmann, M., Tartari, V., Mckelvey, M., Autio, E., Brostrom, A., ... Sobrero, M. (2013). Academic engagement and commercialisation: A review of the literature on university-industry relations. Research Policy, 42, 423-442. Retrieved from https://doi.org/10.2139/ssrn.2088253

Pessoa, L. C., Brito, S. C. C., Muniz, S. M., \& Souza, R. A. (2012). Parques tecnológicos brasileiros: uma análise comparativa de modelos de gestão. Revista de Administração e Inovação, 9(2), 250-270. Retrieved from http://www.revistas.usp.br/rai/article/view/79271

Purdy, J. M. (2012). Framework for Assessing Power in Collaborative Governance Processes. Public Administration Review, 72(3), 409-417. Retrieved from https://doi.org/10.1111/j.1540-6210.2011.02525.x

Rajalo, S., \& Vadi, M. (2017). University-industry innovation collaboration: Reconceptualization. Technovation, 62(63), 42-54. Retrieved from https://doi.org/10.1016/j.technovation.2017.04.003

Robertson, P. J., \& Choi, T. (2012). Deliberation, Consensus, and Stakeholder Satisfaction. Public Management Review, 14(1), 83-103. Retrieved from https://doi.org/10.1080/14719037.2011.589619

Rodrigues, C., \& Melo, A. I. (2013). The Triple Helix Model as Inspiration for Local Development Policies: An Experience-Based Perspective. International Journal of Urban and Regional Research, 37(5), 675-1687. Retrieved from https://doi.org/10.1111/j.1468-2427.2012.01117.x
Saavedra, C., \& Budd, W. W. (2009). Climate change and environmental planning: Working to build community resilience and adaptive capacity in Washington State, USA. Habitat International, 33(3), 246-252. Retrieved from https://doi.org/10.1016/j.habitatint.2008.10.004

Sant'Anna, L. T., Tonelli, D. F., \& Abbud, E. B. (2016). Collaborative Governance: a Maturity Level Proposal based on a Scoping Study (pp. 1-16). In Anais do 40 Encontro da ANPAD, Costa do Sauípe, BA.

Schmidt, S., \& Balestrin, A. (2014). Projetos colaborativos de P\&D em ambientes de incubadoras e parques científico-tecnológicos: teorizações do campo de estudo. Revista de Administração $e$ Inovação, 11(2), 111-131. Retrieved from http://www.revistas.usp. $\mathrm{br} / \mathrm{rai} /$ article/view/100136

Scott, T. (2015). Does Collaboration Make Any Difference? Linking Collaborative Governance to Environmental Outcomes. Journal of Policy Analysis and Management, 34(3), 537-566. Retrieved from https://doi.org/10.1002/pam.21836

Silva, F. Q. B., Suassuna, M., \& Maciel, S. M. (2009). Um modelo de desenvolvimento local baseado em inovação e o papel dos parques tecnológicos na sua implantação. Revista da Micro e Pequena Empresa, 3(1), 25-37. Retrieved from https://doi.org/10.6034/58

Steiner, J. E., Cassin, M. B., \& Robazzi, A. C. (2008). Parques tecnológicos: ambientes de inovação. São Paulo, SP: Instituto de Estudos Avançados de São Paulo.

Tolbert, P. S., \& Zucker, L. G. (1996). The Institutionalization of Institutional Theory. In S. R. Clegg, C. Hardy, \& W. R. Nord (Eds.), Handbook of organization studies (pp. 75-190). London, UK: Sage.

Tonelli, D. F., Costa, H. A., \& Sant'Anna, L. T. (2018). Governança colaborativa em parques tecnológicos: estudo de Casos em Minas Gerais.Gestão \& Regionalidade, 34(101), 152-167. Retrieved from $\mathrm{http}: / / d x . d o i . o r g / 10.13037 /$ gr.vol34n101.3866

Tonelli, D. F., Marquesini, M. A., \& Zambalde, A. L. (2015). Implantação de Parques Tecnológicos como Política Pública: Uma Revisão Sistemática sobre seus Limites e Potencialidades. Revista Gestão \& Tecnologia, 15(2), 113-134. Retrieved from https://doi.org/10.20397/2177$6652 / 2015 . v 15 i 2.632$

Tonelli, D. F., Sant'Anna, L., Abbud, E. B., \& Souza, S. A. S. (2018). Antecedents, process, and equity outcomes: A study about collaborative governance. Cogent Business \& Management, 5, 1-17. Retrieved from https://doi.org/10.1080/23311975.2018.1469381

Vásquez-Urriago, A. R., Barge-Gil, A., \& Rico, A. M. (2016). Science and Technology Parks and cooperation for innovation: Empirical evidence from Spain. Research Policy, 45, 137-147. Retrieved from https://doi.org/10.1016/j.respol.2015.07.006

Vedovello, C. A., Judice, V. M. M., \& Maculan, A. M. D. (2006). Revisão crítica às abordagens a parques tecnológicos: alternativas interpretativas às experiências brasileiras recentes. Revista de Administração e Inovação, 3(2), 103-118. Retrieved from http://www.revistas.usp. $\mathrm{br} / \mathrm{rai} /$ article/view/79066

Weber, E. P., \& Khademian, A. M. (2008). Wicked Problems, Knowledge Challenges, and Collaborative Capacity Builders in Network Settings. Public Administration Review, 68(2), 334-349. Retrieved from https:// doi.org/10.1111/j.1540-6210.2007.00866.x 
Institutional, inter-organizational, and financial factors in science parks: a study from the perspective of collaborative governance
Lindsay Teixeira Sant'Anna | Dany Flávio Tonelli Teresa Cristina Monteiro Martins | João Paulo Nascimento da Silva Luiz Marcelo Antonialli
Weber, E. P., Lovrich, N. P., \& Gaffney, M. J. (2007). Assessing Collaborative Capacity in a Multidimensional World. Administration \& Society, 39(2), 194-220. Retrieved from https://doi. org/10.1177/0095399706297213

Zen, A. C. (2005). A articulação e o desenvolvimento dos parques tecnológicos: O caso do Programa Porto Alegre Tecnópole - Brasil.
In Anales do 11오 Seminário Latino Americano de Gestión Tecnológica, Porto Alegre, RS.

Zouain, D. M., \& Plonski, G. A. (2006). Parques tecnológicos: Planejamento e Gestão. Brasília, DF: Anprotec: Sebrae.

Lindsay Teixeira Sant'Anna

ORCID: https://orcid.org/0000-0003-2311-111X

Ph.D. in Administration from the Federal University of Lavras (UFLA); Professor at Integrated Adventist Colleges of Minas Gerais (FADMINAS).

E-mail: lindsaysantanna@gmail.com

Dany Flávio Tonelli

ORCID: https://orcid.org/0000-0002-4307-6430

Ph.D. in Administration from the Federal University of Lavras (UFLA); Associate Professor from Department of Administration and Economics at Federal University of Lavras (DAE/UFLA). E-mail: danytonelli@gmail.com

Teresa Cristina Monteiro Martins

ORCID: https://orcid.org/0000-0002-3739-7772

Ph.D. student in Administration at the Postgraduate Program in Administration at the Federal University of Lavras (PPGA/DAE/UFLA) E-mail: teresacristina.ufla@gmail.com

João Paulo Nascimento da Silva

ORCID: https://orcid.org/0000-0002-3956-823X

Ph.D. student in Administration at the Postgraduate Program in Administration at the Federal University of Lavras (PPGA/DAE/UFLA).

E-mail: jpnsilvas@gmail.com

Luiz Marcelo Antonialli

Ph.D. in Administration from the University of São Paulo (FEA/USP); Full Professor from Department of Administration and Economics at Federal University of Lavras (DAE/UFLA).E-mail: Imantonialli@ufla.br 